\title{
Geographers Mobilize: A Network-Diffusion Analysis of the Campaign to Free Ghazi-Walid Falah ${ }^{1}$
}

\author{
Mark de Socio \\ Department of Geography \& Geosciences, Salisbury University, USA; \\ mxdesocio@salisbury.edu
}

\begin{abstract}
In summer 2006, Professor Ghazi-Walid Falah, a political geographer and editorin-chief of the journal Arab World Geographer, was arrested by Israeli police after taking photographs of rural landscapes in Northern Galilee. Falah was subsequently held for 23 days, incommunicado, and without charge. An international campaign to "Free Ghazi" was launched by his family, friends and colleagues, largely over academic listservs and other media. Utilizing social network analysis and contextualizing the campaign within structures of telecommunications technologies, the purpose of this paper is to assess the various factors that contributed to the campaign's coalescence, its rapid development, and its global reach.
\end{abstract}

Keywords: social networks, scale, political geography, Internet

\section{Introduction}

Kirby (1992:236) defines geography as what "geographers choose to do". Ghazi-Walid Falah (2007:588) demonstrates that what geographers choose to do can, at times, be dangerous. Falah, for example, chose to research and write on the political geography of Palestine and Israel, beginning with his dissertation 25 years ago (Falah 1983). According to Falah, this career program of research runs counter to the hegemonic discourse-historical, political, or otherwise-concerning the geographies of Palestine and Israel (see, for example, Falah 1991, 1994, 1996, 2003). Consequently, Falah found himself under suspicion by the Israeli government as both a Palestinian and as a "rogue" scholar of political geography writing of the contested territories of Palestine/Israel within the broad framework of critical geopolitics (Morrissey 2006). In July 2006, several days prior to the outbreak of war between Israel and Hezbollah in Lebanon, Professor Falah was arrested in Northern Galilee, accused of spying for various entities ${ }^{2}$, and held incommunicado for 23 days without charge (Gravois 2007a). In a recent interview with Falah in The Chronicle of Higher Education, reporter John Gravois writes:

Antipode Vol. 42 No. 22010 ISSN 0066-4812, pp 310-335 doi: $10.1111 / \mathrm{j} .1467-8330.2009 .00749 . x$ 
Looking back, Mr. Falah believes that his scholarly record—far from protecting him —only fueled the suspicions that surrounded him [when he was arrested]. Once the interrogation began, he says, his entire career was turned against him: his scholarship on the contested landscape of Israel; his network of colleagues in the Arab world; and his longstanding rivalries with powerful figures in Israeli academe. (Gravois 2007a:1-2)

In a guest editorial in the journal Society and Space, Falah adds, "I was arrested ... because I [am] Ghazi-Walid Falah ... a scholar who has consistently refused to adhere to writing the geography of Israel/Palestine as defined by the Israeli geography guild. I was arrested for my scholarship - seized in the very topography of what I study" (Falah 2007:589).

The response among geographers and scholars to Falah's arrest was quick and vast. Within hours of Falah's arrest, an international campaign to "Free Ghazi" was launched by his family, friends and colleagues. This campaign consisted of an email and letter-writing effort to pressure the government of Israel to either officially charge Falah or release him. In addition to email and letter-writing, a media campaign ensued. Geographers and other scholars and activists wrote letters to the editors of numerous newspapers around the world, conducted interviews on radio, and contributed articles to newspapers and activist websites. The campaign culminated with the establishment of an online petition. Scholars, activists and concerned citizens were encouraged through a range of professional email listservs and websites to write to officials of numerous governments and to sign the on-line petition.

What is remarkable about the Free Ghazi campaign was the speed of its development and the reach of its efforts. Despite a gag order and media blackout imposed by the state, news of Falah's arrest whipped around the globe in a matter of hours, and the campaign for his release was launched within days. The purpose of this paper is to assess the various factors that contributed to the campaign's coalescence, its rapid development, and its global reach.

The paper proceeds by situating the Free Ghazi campaign within three separate bodies of literature in the next three sections that are not generally related. The nature of Falah's detention and that of the campaign for his release brings together these variant topics that comprise widely different sets of issues. The second section reviews literature concerning telecommunications technologies with the aim of exploring two broad themes. Specifically, this includes literature concerning the software ListServ and the nature of the physical construction of the Internet. Both shape the nature of how information disseminates among interconnected networks of geographers, scholars of other academic disciplines, and community activists. Additionally, the uneven development of cyberspace (the "digital divide") places 
constraints on the flow of information, which in turn limits the "spaces of engagement" (Cox 1998) to particular geographies. The second theme of the technology literature concerns the Internet as a site for political activism and counter-hegemonic discourse.

The third section considers literature regarding networks and how individuals mobilize others on behalf of a social cause or concern. The paper draws on social network analysis to demonstrate how the networks employed in the Free Ghazi campaign were mobilized by key actors that enjoy a high degree of centrality in the particular networks with which they are embedded, such as academic disciplines and sub-disciplines. Centrality in this case does not equate with degree of connectivity, at least in the traditional sense, as the literature on the nature of ListServ and the Internet will demonstrate. Rather, centrality in this case is a consequence of scholarship activity over a period of several years, including presenting research at academic conferences and publishing articles in highly-regarded peer-reviewed journals. Hanson (2000:757), for example, writes:

Networking ... takes place every time one speaks at a professional meeting, submits a paper to a journal, reviews ... a manuscript for a journal, publishes a book or an article, teaches a course, serves on a committee, or posts a message on a listserv.

Perhaps the most overlooked — and often the most powerful—venue for networking is publishing, a way to connect not only with distant colleagues from around the globe but also with people working on different but related problems.

From this standpoint, clearly the more one publishes articles in peerreviewed journals, publishes a book, presents at academic conferences, and otherwise engages with the discipline in a myriad of ways that is consistent with research and scholarship, the larger one's network of colleagues and peers becomes, and the more "central" one is in the network.

The fourth section considers the Free Ghazi campaign within the framework of scale as lived experience. Masuda and Crooks (2007:257258) note that an experiential approach to scale privileges human agency and the human body in their intimate encounters with extralocal structures, like governments and economies. What greater intimacy is there between the extra-local (in this case, the State of Israel) and the human body (in this case, the person of Ghazi-Walid Falah) than the state's incarceration and torture ${ }^{3}$ of the body and mind? Further, a community of geographers and scholars was affected in an experiential way; a known and respected colleague had been arrested and held without charge for 23 days. The unimaginable specter of Guantanamo Bay, Abu Ghraib, the War on Terror, and rendition had, in a personal way, touched the community of geographers and scholars of Middle 
Eastern studies. The probability that Falah was targeted because of his scholarship activity - for doing geography — makes the experience even more immediate.

The fifth section presents the various forms of data collected to document the breadth and depth of the Free Ghazi campaign, and the speed of its diffusion, and the methodology employed in the analysis of the Free Ghazi campaign, namely a qualitative network-diffusion analysis. The sixth section chronicles the Free Ghazi campaign from a social network perspective, the seventh section summarizes the analysis, and the final section provides concluding remarks.

\section{Network Topology, the Internet, and ListServ}

In the late 1950s and early 1960s, computer scientists and engineers at the Advanced Research Projects Agency (ARPA) of the US Department of Defense were tasked with improving the US military's communications and defense technologies, largely in response to Soviet successes in missile and satellite technologies (Hafner and Lyon 1996). Meanwhile, in a contract with the US Air Force, the RAND Corporation was charged with developing a network communications topology that would allow several communications systems separated by long distances to interact with each other (Baran 1964). A technology that eventually emerged from these two thrusts of research was "packetswitching" in which digital information is broken up into bundles (or "packets") and transmitted from one point, or computer, to another (Hafner and Lyon 1996:59-60; Grubesic, O' Kelly and Murray 2003:54). If a link in the routing structure is slowed, blocked, or destroyed, the data would be sent on to its final destination via the next-available shortest route where it awaits to be joined with remaining incoming packets containing the rest of the data, which are then combined and the information "re-constructed" at its final destination. This process is essentially how email works and is the infrastructural foundation of the Internet (Hafner and Lyon 1996).

The successful implementation of this network system, dubbed ARPANet, and further modifications of network technologies, spurred other institutions to develop networks of their own, such as the "Because Its Time Network" (BITNET), the National Science Foundation Network (NSFNet), and others. Further modifications facilitated the ability to link these disparate networks, creating networks of networks that eventually morphed into the modern Internet.

BITNET, which emerged in the mid-1980s, developed a method for simultaneous communication with large groups of people irrespective of their location. Their method became known by its software, ListServ. The concept was a simple one based on the marketing tool of distribution lists in which a group of emails are collected into a list that are included 
in a single collective email address that the software ListServ reads as something like "send this message to all emails on the list" (Hyman 2003:19). ListServ became a popular tool for academics of particular fields and interests, and scholarly electronic forums using the software proliferated across universities and academic disciplines in the 1980s and 1990s. Such forums allow for quick dissemination of information on the one hand, and exchanges of ideas among multiple members on the other. Although BITNET disappeared by the mid-1990s, ListServ and ListServ-based discussion groups remain popular today and, indeed, are essential aspects of academic life (Hyman 2003:18).

Whole communities of scholars and hobbyists have developed around ListServ-based discussion groups, and geographers are no exception. The Association of American Geographers (AAG), the premier organization of scholars and professional practitioners of geography in the USA, contains 59 sub-organizations, or specialty groups, representing multiple specializations and interests contained within the discipline of geography. Most of these specialty groups have a ListServ-based Internet discussion group of their own for which to share information and ideas among subscribed members. As these specialty groups demonstrate, the organizing principle of ListServ-based discussion groups is that of community membership based on common interests rather than geographical location. Hyman (2003:19) refers to such ListServ-based communities as "virtual tribalism". However, these scholarly Internet communities are not closed as the metaphor of virtual tribalism might suggest. Rather, members of one scholarly discussion group are very likely members of any number of other scholarly discussion groups, forming linkages or "interlocks" between multiple discussion groups. These interlocks among discussion groups are unlike interlocks among other organizations such as boards of directors of various corporations and civic organizations. Whereas interlocking directorates are comprised of business and social leadersand by invitation only, based on the significant resources individual leaders bring to the corporation or organization (de Socio 2007, 2010)interlocking discussion groups are created by the rank-and-file members themselves who are simply following their own intellectual interests. There is, conceivably, no limit to the number of discussion groups interlocked by subscribers.

Many writers and academics have heralded the proliferation of ListServ-based discussion groups and the Internet as egalitarian in nature, as "great equalizers" allowing for a wide range of voices and discourses to be promulgated and new identities formulated, despite the hegemonic origins of the Internet itself as a network linking research institutions under contract with the US Department of Defense and as a way to improve command-and-control systems of the US military (Adams 1998: 100; Hyman 2003; Johnson-Eilola and Selber 1996; 
O'Lear 1997; Warf and Grimes 1997). The openness of the Internet, however, inevitably tends to draw in and reproduce perspectives and opinions that pervade wider society, including racism, sexism, and a host of other "unpalatable" ideologies (Warf and Grimes 1997: 260). This online reproduction and reinforcement of wider social and power relations thus distorts and constrains notions of the Internet as emancipatory and/or egalitarian. Additionally, state policing efforts of online activities tend to suppress political activism as seen in China (Hadlock 2005) and Vietnam (Surborg 2008). Nevertheless, all sorts of counterhegemonic discourses, including left-wing and right-wing, have found the Internet to be a useful medium for promoting their views and encouraging discussions and networking among like-minded individuals and groups (Warf and Grimes 1997).

It is important to note that the spaces of counterhegemonic discourse and political resistance, or spaces at the "margins" that are not fully integrated into contemporary power structures (Steinberg 1994: 462) - spaces that the Internet embodies - are limited to areas where the physical infrastructure of the Internet is present. Miller (1994) demonstrates how "local opportunity structures", which in the case of the Free Ghazi campaign includes infrastructure and technologies like the Internet and ListServ-based discussion groups, contributes to the shape and form that political resistance takes. As these technologies diffuse globally, new spaces arise for political mobilization and counterhegemonic discourses (Adams 1996; O'Lear 1997; Staeheli et al 2002), even to the point of undermining state control of information (Adams 1996; Froehling 1997). As will be shown in the following sections, the Free Ghazi campaign took on a particular geographical structure that was both enhanced and constrained by telecommunications technologies, namely that of the Internet and ListServ-based discussion groups.

\section{Social Network Analysis}

Rather than viewing the actions of individuals as autonomous, driven, for example, by one's personal attributes, the perspective of social network analysis views the actions of individuals as "arising out of structural or relational processes" and therefore focuses inquiry into "properties of the relational system" (Wasserman and Faust 1994:7-8). The Internet and ListServ-based discussion groups represent one such relational system, as do memberships in the AAG, specialty groups of the AAG, and other scholarly organizations. Publishing articles in peerreviewed journals is another form of a relational system, connecting the author with readers and with other authors through citations and references. 
Within social network analysis, several levels of analyses are embedded. Networks can be analyzed at the level of nodes (comprised of entities such as individual people, firms, or countries), groups (for example, industry or other sectors), or at the level of an entire network system. Two important concepts in network analysis are centrality and density. Degree of centrality indicates a node's overall positionality in a network of interconnected entities and is measured as the total number of ties a node has with other entities in the network. Entities with a low number of ties are considered to be marginal within the network in which it belongs. The higher the number of ties, the more important an entity is by virtue of its connectedness with other entities in the network. By being more central in the network, an entity is regarded as more influential because information can easily pass from it to many other entities in the network. Density is a ratio of the number of actual ties within a network and the sum of all possible ties, and takes on a value between 0 and 1 ; the closer to 1 , the more dense the network.

Research in organizational network theory and community power studies utilizing interlocking directorates demonstrate the utility of social network analysis in uncovering central actors and power relations among groups of interconnected individuals, firms, and economic sectors. For example, banking and financial firms have been found to enjoy a high degree of connectivity, or "centrality", within networks of corporations, particularly among manufacturing firms in financial distress (Lang and Lockhart 1990; Mintz and Schwartz 1983, 1985; Mizruchi and Stearns 1988). Additionally, interlocking directorates appear to be an effective conduit for knowledge and information dissemination among interlocked firms. In a study of mergers and acquisitions, for example, Haunschild (1993) found that firms tend to more closely imitate other firms with which they share interlocking directorates. A firm appeared more likely to engage in merger and acquisition activities when one or more of its directors or executives served as a director in another firm that had previously been involved in a merger or acquisition. Geletkanycz and Hambrick (1997), meanwhile, found that firms tend to conform to wider industry trends relative to the degree with which they are interlocked with other firms in their sector.

In social network terminology, interlocking directorates are "shared events"- the event is sitting on a board of directors. The Free Ghazi campaign also represents a network system in which actors are linked to each other by events - in this case, shared memberships in professional organizations, ListServ-based discussion groups, or other such organizations (see Wasserman and Faust 1994:291-292). Actors in the Free Ghazi campaign are also linked via the nature of academic work; that is, by engaging with or having published research in a particular set of interrelated academic journals of sub-disciplines, namely political geography, geopolitics, critical geopolitics, and Middle 
Table 1: Select academic journals in which Falah has published that publish articles related to political geography, Middle Eastern studies and related sub-disciplines, and their impact factors

\begin{tabular}{lcc}
\hline & Impact factor & No. of articles authored by Falah \\
\hline Geography Journals & & 2 \\
Annals of the AAG & 2.141 & 2 \\
Geoforum & 1.664 & 1 \\
Environment and Planning D & 1.495 & 5 \\
Political Geography & 1.440 & 2 \\
Antipode & 1.287 & 1 \\
Professional Geographer & 1.046 & 4 \\
Arab World Geographer & N/A & \\
Multidisciplinary Journals & & 4 \\
Third World Quarterly & 0.642 & 4 \\
Journal of Palestine Studies & N/A & 25 \\
& Total & \\
\hline
\end{tabular}

Eastern studies (Table 1). Actors considered the most "central" or prestigious in such affiliation networks are those that have the highest number of links to other actors in the network and are therefore the most "visible" (Wasserman and Faust 1994:172). These actors are the "most involved" (Wasserman and Faust 1994: 173). Similarly, to be visible in academics generally means publishing research in peer-reviewed journals, particularly in journals with high "visibility"- those that enjoy the greatest number of citations in published research papers within and across academic disciplines (Hanson 2000; Levia and Underwood 2004; Quiring 2007).

Falah has published more than 40 peer-reviewed articles spanning 24 separate academic journals throughout his 25-year career as a professional geographer. Table 1 lists select academic journals that publish articles related to political geography, Middle Eastern studies and related sub-disciplines, and their impact factors. In addition, Table 1 depicts the number of articles these particular journals published that were authored and/or co-authored by Falah. Of the more than 40 peer-reviewed articles published by Falah, 25 of these appeared in the 10 particular journals presented in Table 1. Falah clearly enjoys visibility, or "centrality", in the sub-disciplines of Middle Eastern studies and political geography by virtue of his record of scholarship. Additionally, Falah has presented research at a number of academic conferences internationally: consistently at annual AAG conferences, a conference on "America in the Middle East/The Middle East in America" at the American University of Beirut (2005), the "Beirut Conference on Public Spheres" (2005), the "Gulf First Urban Planning and Development Conference and Exhibition" in Kuwait (2004), and 
the "Second International Congress of the Geographers of the Islamic World", held in Tehran (2003), to highlight just a recent few. Thus Falah's network of colleagues extends internationally.

Falah's visibility undoubtedly played a role in the speed and reach of the Free Ghazi campaign; many academics spanning disciplines surely recognized Falah's name and were familiar with his work. This is not to say that a neophyte scholar-like this author, perhaps-if found to be in an equally dreadful situation would not garner a similar response among colleagues. At least one can hope. However, it will be clear that several actors were key to the rapid growth and success of the Free Ghazi campaign, and that these actors, who themselves enjoy a relatively high degree of visibility in the areas of political geography, geopolitics, and/or Middle Eastern studies, were particularly close (or "adjacent", in social network terminology) to Falah in several ways: as a former or current colleague of Falah working in the same department as he; as co-author with Falah in a current or previous research project and/or publication; interacted in some way with Falah in his capacity as Editor-in-Chief of the journal The Arab World Geographer ( $A W G$ ); or served with Falah on an editorial board other than $A W G$. This point should serve as a reminder of the importance of social networks in everyday (professional) life that Hanson (2000) so elegantly enunciated.

Finally, the closeness of the actors involved in the Free Ghazi campaign with Falah himself also demonstrates the utility of perceiving scale as lived experience. It is to this point the paper now turns.

\section{Scale as Lived Experience}

The concept of scale has undergone a great deal of scrutiny and debate over the past 20 years (see, for example, Jonas 2006; Leitner and Miller 2007; Marston, Jones and Woodward 2005; Paasi 2004). This debate has been a healthy exercise for geographers and others; it has led to a deeper understanding of the nuances of what was once considered to be a straightforward concept of scalar hierarchies, depicted as "levels" (or "sizes") ranging from top to bottom: global, national, regional, local, neighborhood, household, individual (Delaney and Leitner 1997:93; Marston, Jones and Woodward 2005:420). Particular spatial processes were seen as inherent to particular "levels". For example, foreign policy was seen as conducted at the level of "global", suburbanization was seen as a phenomenon occurring at the "regional" scale, and so on. Scale has since come to be seen as socially constructed (Paasi 2004). Agnew (1997), for example, demonstrates how in the 1990s the emerging Italian political party, the Northern League, defined itself as a regionally based political party opposed to the "national" scale of politics in Italy that, in the view of the Northern League, had come to privilege the Mezzogiorno region of southern Italy. Miller (1994), meanwhile, demonstrates how 
anti-nuclear activists in Worcester, Massachusetts consciously sought to create a local "nuclear-free zone" and ban nuclear-related research and other activities. This "from below" strategy forced extra-local actors like Raytheon and other defense contractors with local operations to "come down" in scale and engage with the local community in a concerted effort to defeat the proposed ban on nuclear-related activities, a "local" ban that, if enacted, would have much wider impacts on corporate operations. Conversely, Cox (1998:1-2) demonstrates how local actors blocked by local authorities are able to circumvent the "local" scale and engage with the "regional", "national", or "global" level of politics in pursuit of redress, in essence "jumping scales". In each of the case studies reviewed by Cox (1998), networks were essential to both "jumping" scales and in "coming down" in scale to engage with local communities (see, eg, Cox and Wood 1997; Miller 1994).

This reworking of scale as relational implies spatial interaction in a way that scale-as-levels does not by privileging nodes, including the human body, in relation to other nodes, whether other bodies or institutions, including extra-local institutions (Masuda and Crooks 2007). Gieseking (2007:281), for example, demonstrates how women on university campuses have used their bodies "to negotiate the campus", including dressing in ways that challenged campus attire regulations, or by studying and excelling in academic disciplines that were deemed by wider society as off-limits to women. Staeheli and Thompson (1997) demonstrate how a marginalized group of "countercultural" youth in Boulder, Colorado challenged redevelopment efforts of their favorite space for socializing, an area near the University of Colorado known as "The Hill". These youth used their very presence, their bodies, in addition to implements like spray paint cans, to fight against an effort aimed at their physical displacement that included extra-local ${ }^{4}$ institutions like the Boulder Police and the city government.

Telecommunications technologies also have implications for scale. Adams (1996), for example, demonstrates that communications technologies-built in ways that primarily solidify and centralize capitalist power (1996:420)—can be "piggy-backed" or otherwise utilized by subordinated groups for purposes of escaping the confines of political and physical space in order to petition their cause to wider audiences. Adams shows how the pro-democracy protesters of Tiananmen Square in 1989 utilized the global media spectacle of Soviet Premier Mikhail Gorbachev's historic visit to China to stage their protest and appeal for global support on the one hand and for the exertion of external pressure on the Chinese government for democratic reforms on the other, reforms that Gorbachev himself embodied in his push for perestroika and glasnost in the Soviet Union. Similarly, the Civil Rights movement in the USA relied on the television media to cover the violent reprisals of Bull Connor, the police chief of Birmingham, 
Alabama, in the 1960s in order to garner the sympathies of citizens in the USA and around the world (Adams 1996). Additionally, the telephone was utilized by Civil Rights leaders across the country to share information and keep each other apprised of successful strategies and of news of significant events. Tiananmen Square and the Civil Rights movement both demonstrate how individual people were able to use their bodies in interaction with particular telecommunications technologies to "jump scales" and disseminate information past official "gatekeepers" and at the same time appeal to wider audiences for moral, if not material, support (see D' Arcus 2006, for further case studies and a more fuller exploration of the interactions and relations between bodies (nodes), media and states, and their implications for the politics of scale).

In a relational approach to globalization, Yeung (1997, 2005) demonstrates how foreign direct investments are facilitated through business and familial networks. Specific persons (nodes) comprise such networks, and these networks, similar to urban political coalitions, are built on intimacy, or "trust", among the persons comprising the network (Yeung 1997, 2005; Stone 1989; Wood 1993). "Trust" implies experience and is developed after a period of trials (see Tuan 1977:9). Thus, when we say that scale is relational, we are also saying that scale is experiential. In urban politics, trust is seen as the basis of regime coalitions and economic development networks (Stone 1989; Wood 1993), whose networks often transcend space and scale-as-"levels" (see, eg, Tretter 2008; Wood 2005).

In academics, networks are no less about trust and reliability (Liebeskind and Oliver 2000). Academic networks develop as a result of scholarship activities built upon shared intellectual curiosity and interests, and are embodied by shared memberships in professional academic organizations like the AAG, shared participation in subfields embodied, for example, in the AAG specialty groups, and through such mediums as publishing books, publishing research papers in peerreviewed journals, attending conferences, and the like (Hanson 2000). Electronic media has allowed such networks to expand to include shared memberships in ListServ-based scholarly discussion groups, and through email communications. Spatially, such networks can (and do) span the globe, but are limited to places where such media infrastructure is in place. Other constraints like language barriers and academic hegemony place further limits on the reach of such networks.

The campaign to Free Ghazi arose out of just this sort of pre-existing network. Interaction among colleagues in academic networks like the one described above is experiential in nature. However, the arrest and detention of Falah represents a different sort of "experience", but it was nevertheless an experiential event for the network as a whole, particularly among those most adjacent to Falah himself. The paper 
now turns to an assessment of this particular experience, the arrest and detention of Ghazi-Walid Falah, and the network's response.

\section{Data and Methodology}

Much of the data collected for this study is primary; Professor Falah generously shared email correspondence between family members and colleagues as they worked together towards developing and sustaining the Free Ghazi campaign. In addition, an online petition established just days before it was to be presented at a scheduled court hearing for Falah garnered more than 1500 individual signatures, of which 1190 were scholars who listed a university affiliation. This petition presents a chronology of signatures and locational data (listed university affiliations). Other data sources include announcements on ListServbased discussion forums, and correspondence among members of specialty groups of the AAG, members of the Middle Eastern Studies Association (MESA), and other academic organizations, disciplines and sub-disciplines. Finally, the majority of scholars identified as members of the wider professional network of Ghazi-Walid Falah generously provided up-to-date curriculum vitaes outlining co-publications, coeditorships, and so on. Secondary data sources include news accounts, articles, blogs, and interviews on television and radio written or performed by geographers in an effort to publicize Falah's plight.

As with any social network analysis, among the first of problems to overcome is to identify the network and to limit its extent for analysis (Wasserman and Faust 1994:292-293). The nature of academic networks presents a particular problem for analyzing the Free Ghazi campaign. First, interlocking discussion groups, academic affiliations, and the like, are consummated by the rank-and-file members based entirely on one's own interests. Consequently, there is, conceivably, no limit to the number of discussion groups and affiliations interlocked by rank-and-file members. Second, the usual measurements for social network analyses, such as degree centrality, betweenness centrality, closeness centrality, and network density, require data such as the number of ties linking each of the individuals (nodes) comprising the identified network. Given the nature of the Free Ghazi campaign, that is, it's use of the Internet and ListServ-based discussion groups for correspondence among members and dissemination of information presents a challenge for the collection of such data. The nature of ListServ-based discussion groups is such that all members are connected to each other. No members enjoy "centrality" in such a schema. Further, any decision on the part of individuals to act in response to news posted on several ListServ-based discussion groups was purely voluntary and, in most cases, anonymous; that is, individuals most often wrote letters to 
officials and newspaper editors independently and without announcing such action in the ListServ-based discussion groups.

Given these constraints, a more qualitative approach is justified in lieu of traditional quantitative social network analysis. The available data allow for mapping the chronology of events and of the Free Ghazi campaign, and key individuals - the actors most central to the Free Ghazi campaign-emerge from such an approach, as does the nature of relations among various actors within the Free Ghazi campaign. Finally, the online petition encompassing 1190 signatures with university affiliations provides a good indication of the extent of the campaign's reach. Indeed, all individuals (though limited) who are identified as having played some role in the Free Ghazi campaign — from initial organization of the campaign to independently writing letters and articles or conducting interviews - are known to have also signed the petition.

\section{"We all know Ghazi": The Campaign to Free Ghazi-Walid Falah}

Events that led to the Free Ghazi campaign began on 8 July 2006 when Professor Falah, a tenured professor of geography at the University of Akron in Akron, Ohio, was arrested in Israel, his country of birth, after taking photographs of the scenic countryside in the Northern Galilee for possible use in The Arab World Geographer, an academic journal for which he serves as Editor-in-Chief. ${ }^{5}$ He would be detained for the next 23 days without charge.

After several hours of interrogation, the Shin Bet, Israel's state police, escorted a bound-and-shackled Falah to his brother's home in the middle of the night so that they could search his luggage. It was during this brief visit that Falah's relatives had learned of his arrest. They shared news of Falah's arrest and detention with his immediate family in Akron, but there were no details. An Israeli court-issued gag order forbade Falah to speak with his lawyer and forbade his lawyer from speaking with the press. Further, the gag order forbade the Israeli media from covering the arrest and detention (Gravois 2007a). Further complicating matters and undoubtedly contributing to the length of Falah's detention, a war erupted between Israel and Hezbollah along the Israeli-Lebanese border following a Hezbollah rocket attack on an Israeli border patrol and the kidnapping of two Israeli soldiers just three days after his arrest (Myre and Erlanger 2006).

In Akron, Falah's wife and their three children frantically tried to get information about his arrest. They contacted colleagues of Falah at the University of Akron and informed them of Falah's predicament and requested help in obtaining information. They also sought to get information to Israel that they hoped would help vindicate Falah 
and clear up any confusion as to who he was. University and US government officials were contacted as was the local newspaper, the Akron Beacon-Journal. The first news story to break announcing the arrest and detention of Falah occurred in the Akron Beacon-Journal on 13 July, 5 days after his initial arrest (Biliczky 2006). The next day the story appeared internationally in the Associated Press wire (Sheeran 2006).

In Israel, having learned of Falah's arrest, the newspaper Haaretz contacted Israeli geographer David Newman at Ben Gurion University and a former colleague and previous co-author with Falah, for information about Falah and his background. Newman then contacted Virginie Mamadouh, a co-editor of The Arab World Geographer and previous co-author with Falah, and Professor of Geography at the University of Amsterdam, to seek information on Falah's visit and to inform her of his arrest. In turn, Mamadouh contacted Colin Flint, another co-editor of The Arab World Geographer and previous co-author with Falah, and Associate Professor of Geography at the University of Illinois. Flint, although on summer vacation in Montana, immediately contacted Falah's family in Akron and offered his assistance.

After 2 days of researching relevant contact information for the US, Israeli, and Canadian governments (Falah has dual citizenship in Israel and Canada), the first email correspondence describing Falah's predicament along with a call to action, including contact information of relevant Israeli authorities (specifically, the Israeli Attorney General, the Minister of Justice, and the Public Prosecutor), went out on 16 July. The email was from one of Falah's sons to Daniel Boyarin, professor of Near Eastern Studies and Rhetoric at UC Berkeley. By 19 July, this email in turn was passed along to 19 more colleagues, all of whom work on different but related problems concerning the Israeli-Palestinian conflict. These 19 colleagues each have interacted with Falah in one or more conferences, and they span the globe. Eleven are professors at universities in Israel, including Tel Aviv University and Haifa University. Five work at US-based universities, including Harvard, Michigan, and UC Berkeley. Two work at Canadian universities. The 11 colleagues in Israel in turn concentrated their efforts on disseminating information among their colleagues in Israel and urging them to write letters to the appropriate authorities. For example, one responded to Boyarin and all whom he had emailed with an email encouraging colleagues to follow through on the call to action: "We all know Ghazi. Please write on his behalf and apply any connection you have for his immidiate [sic] release." For their part, one of the colleagues in Canada responded with an email that read: "I've passed along your message to a number of friends working in the Canadian media-I have not seen nor heard any coverage of this here." 
On 18 July, Colin Flint passed along an email similar to that of Falah's son describing Falah's precarious situation and listing contact information of relevant authorities. In addition to a plea for action, Flint elaborated on Falah's academic credentials and made an appeal for academic freedom as a casus belli for involvement in the bourgeoning campaign to Free Ghazi. Flint sent his email to several colleagues, including Peter Taylor at the University of Loughborough in the UK, Derek Gregory at British Columbia in Canada, Anne Buttimer at University College Dublin in Ireland, Audrey Kobayashi at Queen's University in Canada, and Annsi Passi at Oulu in Finland, to name a few key actors that span the globe. Table 2 provides the complete list of contacts to which Colin Flint sent his initial email and later, followup emails with updates concerning Falah's case. The individuals on the list are largely political geographers who research and publish in the tradition of critical geography, and many of these have done work in Middle Eastern studies or work related to the Israeli-Palestinian conflict. From Colin Flint's emails to the list in Table 2, his emails were then passed on to managers of various ListServ-based discussion forums of AAG specialty groups, namely Urban Geography, Economic Geography, and Political Geography, and onward to the Middle Eastern Studies Association.

Also on 18 July, Reecia Orzeck, a PhD student at the time at Syracuse University studying international law in the Israeli-Palestinian conflict, and who was familiar with Falah's work, independently learned of Falah's plight through a news article that appeared in The Chronicle of Higher Education. Subsequently, Orzeck sent an email to several ListServ-based discussion groups simultaneously: the Socialist and Critical Geography Specialty Group of the AAG, the Feminism in Geography discussion group, the Sexuality and Space Specialty Group of the AAG, the Cultural Geography Specialty Group of the AAG, and the departmental ListServ group of the Department of Geography at Syracuse University. Orzeck included an extensive list of relevant contact information that included the President of Israel, the Israeli Prime Minister, the Inspector General of the Israeli Police, the US Secretary of State, the Israeli Ambassador to Canada, and the Canadian Minister of Foreign Affairs. Orzeck's email was in turn forwarded and posted to the ListServ-based discussion group of the Asian Geography Specialty Group of the AAG.

Spurred by the emails posted in these various discussion groups and forums, a wider campaign to Free Ghazi consequently ensued. The AAG, for example, communicated directly with the Israeli Ministry of Justice and with other high-level contacts in both the Israeli and Canadian governments to request that Falah be granted due process (AAG 2006). Additionally, the AAG coordinated with the Israeli Association of Geographers in order to facilitate information exchange 
Table 2: Contact list of Colin Flint to which Flint sent emails and updates detailing the progress of Falah's case

\begin{tabular}{lll}
\hline Name & \multicolumn{1}{c}{ University affiliation } & Country \\
\hline Hussein Amery & Colorado & USA \\
Lawrence Berg & British Columbia & Canada \\
Anat Biletzki & Tel Aviv & Israel \\
Anne Buttimer & University College Dublin & Ireland \\
Mathew Coleman & Ohio State & USA \\
Kenneth Cuno & Illinois & USA \\
Lorraine Dowler & Penn State & USA \\
Tobi Fenster & Tel Aviv & Israel \\
Steven Gasteyer & Illinois & USA \\
Derek Gregory & British Columbia & Canada \\
Lev Grinberg & Ben Gurion & Israel \\
Gillian Hart & Berkeley & USA \\
Andrew Herod & Georgia & USA \\
P.A. Jackson & Sheffield & UK \\
Gerry Kearns & Cambridge & UK \\
Scott Kirsch & North Carolina & USA \\
Audrey Kobayashi & Queen's & Canada \\
Virginie Mamadouh & Amsterdam & Netherlands \\
Tamar Mayer & Middlebury & USA \\
Patrick McGreevy & American University of Beirut & Lebanon \\
Alex Murphy & Oregon & USA \\
David Newman & Ben Gurion & Israel \\
Shannon O'Lear & Kansas & USA \\
John O'Loughlin & Colorado & USA \\
Anssi Paasi & Oulu & Finland \\
Keith Richards & Cambridge & UK \\
Izhak Schnell & Tel Aviv & Israel \\
Eric Sheppard & Minnesota & USA \\
Lynn Staeheli & Colorado & USA \\
Peter Taylor & Loughborough & UK \\
Gerard Toal & Virginia Tech & USA \\
& & \\
\hline & &
\end{tabular}

Note: This contact list is derived from a set of emails that Professor Falah shared with the author. All of the names on the list were contained in the "to" section of Colin Flint's outgoing emails. It is known, however, that Flint kept other individuals, for example John Agnew, abreast of Falah's situation through separate emails. This information came to light through email discussions, but the table reflects only the data in possession of the author.

and to be of assistance to Israeli geographers working for Falah's release. Apart from the AAG's collective efforts, many geographers and scholars of Middle Eastern studies wrote articles that were published in various newspapers or activist websites, blogs, letters to the editor, and open letters to relevant authorities. ${ }^{6}$ Geographers also conducted radio interviews on Canadian and Irish public radio (Morrissey 2006). The extent of letters written to authorities in the US, Canadian, Israeli, and perhaps other, governments, cannot be known. However, by the time 
Table 3: Known list of ListServ-based scholarly discussion groups in which news of Falah's arrest and updates about the progress of his case were posted. These posts also provided contact information for relevant US, Canadian, and Israeli authorities, and a link to an on-line petition calling for Falah's release

\begin{tabular}{lcl}
\hline ListServ-based discussion groups & Members & \multicolumn{1}{c}{ Source } \\
\hline Cultural Geography SG & 265 & 2007 Annual Report \\
Gender in Geography discussion group & 500 & Website \\
Political Geography SG & 529 & 2006 Annual Report \\
Sexuality and Space SG & 130 & 2005 Annual Report \\
Socialist and Critical Geography SG & 295 & 2006 Annual Report \\
Syracuse Department of Geography & 70 & Website \\
Urban Geography SG & 1,388 & 2006-07 Annual Report \\
Academics for Justice Yahoo Group & 362 & Website \\
Total & 6,432 & \\
\hline
\end{tabular}

that the Israeli newspaper Haaretz was able to report on the arrest and detention of Falah on 26 July, the story reported that "academics around the world have organized an international campaign on behalf of Falah calling on Israel to allow Falah due process, and to either present him with an indictment or release him" (Traubmann and Melman 2006).

Table 3 presents the ListServ-based discussion forums of the various AAG specialty groups and other scholarly discussion forums where emails detailing Falah's dreadful situation, including updates of his case along with calls to action and relevant contact information and, finally, a link to an online petition, are known to have been posted. In addition, the numbers of memberships of each group provided by their respective annual reports or websites are presented. The total number of nodes potentially reached by interlocking memberships among these groups alone is $\sim 6432$. Although the actual number is probably much lower considering that not all members of a specialty group are necessarily subscribers to their scholarly forums and that an unknown number of nodes overlap, the reach of the Free Ghazi campaign was nevertheless substantial. Indeed, organizers of the campaign to Free Ghazi established an online petition that was publicly announced on 27 July via postings in the ListServ-based discussion groups. Falah was scheduled for a court hearing on 30 July and the petition was announced in an effort to collect signatures to be presented at Falah's hearing. On 30 July 2006, after enduring 23 days of incarceration, interrogation, and torture, Falah was released without charge. In a little more than the 48 hours that transpired between the email announcing the establishment of the online petition, and news of Falah's release, more than 1500 people around the world had added their names to the online petition, including 1190 spanning 44 countries who listed a university affiliation (Figure 1). 


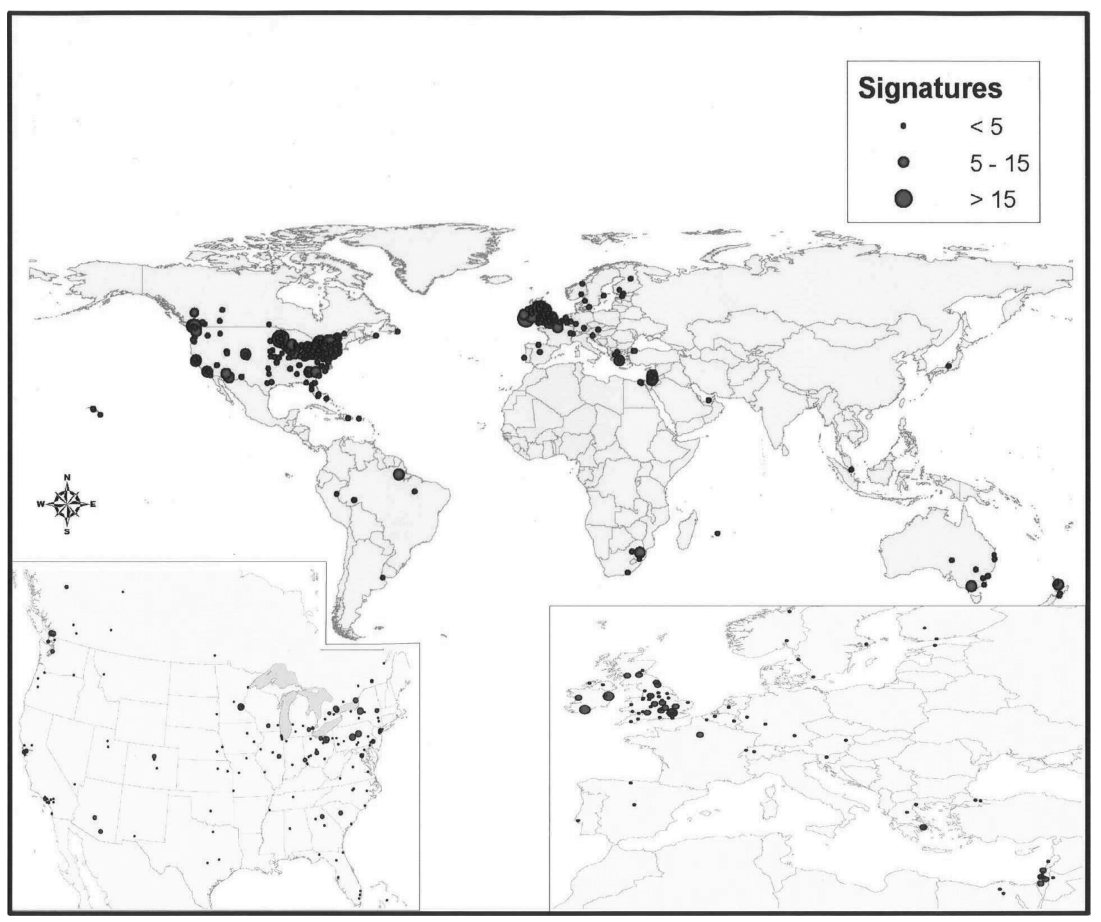

Figure 1: Distribution of university affiliations of signatories of the Free Ghazi on-line petition

\section{Discussion}

The campaign to Free Ghazi did not arise independent of Falah's work as a professional academic. Rather, social network analysis and the notion of scale as fundamentally experiential informs us that a campaign like the one to Free Ghazi would be led by those closest, or most "adjacent", to Falah himself. Hanson (2000), meanwhile, demonstrates that such networks are formed through years of scholarship like publishing research in peer-reviewed journals, attending conferences, publishing books, and the like. And the larger one's record of scholarship, the larger one's professional network. These expectations are clearly borne out in the Free Ghazi campaign. Colin Flint, a political geographer at the University of Illinois, is a central member Falah's professional network. The two co-authored three peer-reviewed papers in the 2 years preceding Falah's arrest, and Flint had published five articles in the Arab World Geographer, a journal for which Falah serves as Editor-in-Chief. Flint also serves as the book review editor for the Arab World Geographer. Flint's action in leading the campaign to "Free Ghazi", then, arose out of the relational system comprising their professional ties and, indeed, it was to this wider relational system that Flint turned in order to mobilize on Falah's behalf (Wasserman and Faust 1994:7-8). 
Table 4: Shared members of the combined immediate professional networks, including once-removed, of Ghazi-Walid Falah and Colin Flint by degree centrality (3 or greater)

\begin{tabular}{llc}
\hline Name & University affiliation & Degree centrality (No. of links) \\
\hline Colin Flint & Illinois & 18 \\
Ghazi-Walid Falah & Akron & 14 \\
Anssi Paasi & Oulu & 13 \\
Peter Taylor & Loughborough & 13 \\
Lynn Staeheli & Colorado & 12 \\
Gerard Toal & Virginia Tech & 12 \\
Virginie Mamadouh & Amsterdam & 11 \\
Don Mitchell & Syracuse & 10 \\
Derek Gregory & British Columbia & 9 \\
Caroline Nagel & South Carolina & 9 \\
John O'Loughlin & Colorado & 9 \\
Fred Shelley & Oklahoma & 9 \\
Gerald Webster & Wyoming & 8 \\
David Newman & Ben Gurion & 7 \\
Andrew Herod & Georgia & 6 \\
Amery Hussein & Colorado & 6 \\
Patrick McGreevy & American University & 6 \\
Stanley Brunn & of Beirut & 5 \\
R.J. Johnston & Kentucky & 5 \\
Janet Kodras & Bristol & 5 \\
Alex Murphy & Florida State & 5 \\
Lawrence Berg & Oregon & 4 \\
Scott Kirsch & British Columbia & 4 \\
Eric Sheppard & North Carolina & 3 \\
Barney Warf & Minnesota & 3 \\
\hline
\end{tabular}

Table 4 presents the relational system comprising the shared members of the combined immediate professional networks, including onceremoved, of both Falah and Flint, ranked by degree centrality or number of ties. These include co-authors and co-editors of Falah and/or Flint, those who share editorial board memberships with Falah or Flint, those who published in the journal Arab World Geographer, and the editor(s) of a book that Falah or Flint has published a chapter in (or vice versa). Figure 2 presents a truncated diagram utilizing the software program UCINET 6.0 (Borgatti, Everett and Freeman 2002) illustrating the linkages among the combined professional networks of Falah and Flint. Note that the diagram includes notable and prominent political geographers just one link removed from either Falah or Flint or both, such as Peter Taylor, Derek Gregory, Don Mitchell, Lynn Staeheli, R.J. Johnston, Fred Shelley, Janet Kodras, Gerald Webster, Lawrence Berg, and several others, many of whom helped organize or participated in the campaign to Free Ghazi. All are intimate members of a wider professional network built over a career now spanning 25 years. It was this pre-existing network of geographers and scholars that, when 


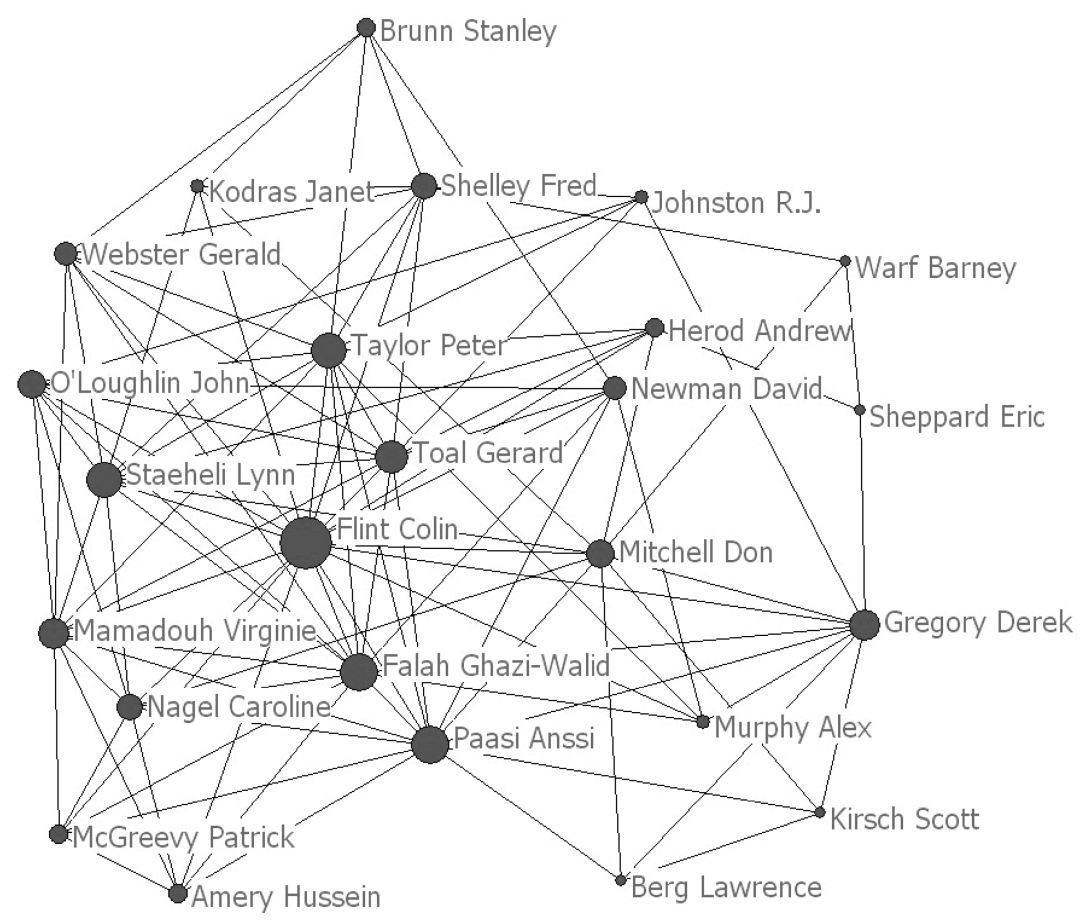

Figure 2: Dyads of the combined immediate professional networks, including onceremoved, of Ghazi-Walid Falah and Colin Flint by degree centrality (three or greater)

mobilized, broadened to include a much wider network of colleagues, co-authors and co-editors of Flint's contact list, and their colleagues, coauthors and co-editors-and so on-until, in a little more than 48 hours after its inception, 1190 scholars spanning 44 countries added their names to the petition calling for Israel to grant Falah due process and to present Falah with an indictment or release him.

\section{Conclusion}

The geography of the Free Ghazi campaign reflects the nature of how the campaign was conducted: in the English language via a pre-existing professional network established over a career of scholarship now spanning 25 years; and through the use of technologies like ListServbased discussion groups and the Internet. Throughout his career, Falah has worked at various universities in several, mostly English-speaking, countries: he did his PhD at Durham University in the UK; he worked at the University of Wales in the UK, at the University of Toronto in Canada, and finally, at the University of Akron where he currently works. The vast majority of his research papers have been published in peer-reviewed, English-language journals in geography and Middle Eastern studies. The geography of the Free Ghazi campaign thus reflects 
Falah's associations in the English-speaking academic world: current and former colleagues at universities in the UK, Canada, and the USA, co-authors of Falah, those who have served on editorial boards with Falah, those who have published in the journal Arab World Geographer for which Falah serves as Editor-in-Chief, and the editor(s) of books that Falah has published a chapter in or vice versa. Beyond these actors more immediate to Falah, his more expansive professional network includes scholars working within the same academic fields as him and are familiar with his work-scholars like Reecia Orzeck, the Syracuse $\mathrm{PhD}$ student who, after learning of Falah's arrest, passed on news of his predicament along with contact information of relevant authorities to at least five separate Listserv-based scholarly discussion forums and potentially reaching more than 700 subscribed members.

That the petition was developed online and over the Internet, and that news and calls to action were shared exclusively over ListServbased discussion groups and emails-essentially "piggy-backing" on modern telecommunications infrastructure-accounts for the speed and reach of the Free Ghazi campaign. The ability of the petition portion of the campaign to reach 44 countries in a span of little more than 48 hours attests to the nature of contemporary electronic media: the lattice-like infrastructural development of the Internet and its routers since its inception by ARPA, and design of the BITNET-created software ListServ to pass information to large numbers of subscribers simultaneously. Three global clusters that captured the most signatures reflect Falah's network in the USA, the UK and Israel. Indeed, Table 5 presents the top 17 universities ranked by number of signatories. With the exception of the University of Melbourne in Australia, the top 17 are comprised exclusively of universities from the three primary clusters of North America, Western Europe, and Israel.

Finally, the notion of scale as fundamentally experiential and that ultimately privileges the body and mind drives home a very frightful aspect of the whole ordeal. When news of Falah's arrest spread, several actors commented that it is possible, if not probable, that Falah was arrested for the very scholarship he is known for. They understood that Falah does not work in isolation; rather, that he is part of a community of scholars with shared interests and much collaboration. Indeed, Falah reports that the focus of his interrogation was an attempt to gather information about colleagues, that is, Arab and Iranian members of the wider network of scholars working specifically on issues related to the Israeli-Palestinian conflict (Falah 2007; Gravois 2007a, 2007b). Most understand that if Falah could be arrested and his scholarship and network of colleagues turned against him, so too it could happen to them-to us. This could surely cow lessassured academics, perhaps particularly neophyte academics early in their careers or those in graduate school, into avoiding investigating 
Table 5: Universities ranked by number of petition signatories (at least seven signatures)

\begin{tabular}{llc}
\hline University & Country & Signature count \\
\hline University of Toronto & Canada & 42 \\
University of British Columbia & Canada & 37 \\
York University & Canada & 37 \\
Queen's University & Canada & 36 \\
University College Cork & Ireland & 34 \\
The University of Akron & USA & 29 \\
Bucknell University & USA & 21 \\
The Pennsylvania State University & USA & 20 \\
Syracuse University & USA & 19 \\
University of Minnesota & USA & 18 \\
City University of New York & USA & 17 \\
Simon Fraser University & Canada & 16 \\
University of California, Berkeley & USA & 13 \\
Queen Mary, University of London & UK & 11 \\
Tel Aviv University & Israel & 11 \\
McGill University & Canada & 10 \\
Newcastle University & UK & 10 \\
UCLA & USA & 10 \\
University of Illinois & USA & 10 \\
University of Melbourne & Australia & 10 \\
University of Washington & USA & 10 \\
Ben Gurion University & Israel & 9 \\
University College Dublin & Ireland & 9 \\
University of Wisconsin & USA & 9 \\
Loughborough University & UK & 8 \\
Manchester Metropolitan University & UK & 8 \\
National University of Ireland & Ireland & 8 \\
Oberlin College & USA & 8 \\
University of Georgia & USA & 8 \\
University of Kentucky & USA & 7 \\
San Francisco State University & USA & 7 \\
University of Arizona & USA & 7 \\
University of Colorado & USA & 7 \\
University of Michigan & USA & \\
\hline & & \\
\hline
\end{tabular}

problems deemed controversial or "political"; cowed, in other words, into self-censorship. ${ }^{7}$ The damage to science that would occur if this went unchallenged need not be spelled out here. The campaign to Free Ghazi turned out to be much more than about freeing Ghazi-Walid Falah. Ultimately, it was about academic freedom, and about freeing the academy from government intimidation.

\section{Acknowledgements}

The author would like to thank Professors John Agnew and Don Mitchell and two anonymous reviewers for their useful comments and suggestions regarding an earlier version of this article. 


\section{Endnotes}

1 This article is dedicated to Professor Ghazi-Walid Falah and all individuals who played a role, no matter how small, in the campaign to "Free Ghazi".

2 The State of Israel never officially accused Falah of spying; rather, the insinuation of spying was leaked to the Israeli media (see Traubmann and Melman 2006). The official reason for Falah's arrest was suspicion of taking photographs of a sensitive military facility, a charge that was ultimately dismissed. After 23 days of detention and interrogation, Falah was unconditionally released.

3 Alfred W. McCoy, Professor of History at the University of Wisconsin at Madison and author of A Question of Torture, was consulted by Chronicle of Higher Education reporter John Gravois. "As to whether he personally considers Mr. Falah's experience torture, Mr. McCoy does not hesitate. 'No question,' he says. 'Sixty hours of sleep deprivation in and of itself is torture"" (Gravois 2007b).

4 "Extra-local" in this context means any organization or institution with jurisdiction beyond "The Hill".

5 For a detailed context and chronology of Falah's visit to Israel, and of his arrest and detention, see Gravois (2007a, 2007b) and Falah (2007, 2008).

${ }^{6}$ For example, John Morrissey, a young political geographer at the National University of Ireland at Galway, conducted a radio interview on Irish public radio to highlight Falah's case (Morrissey 2006). He also helped organize a petition of Irish geographers, capturing a total of 40 signatures of geographers - highly reputable and neophyte alikefrom across Ireland. This petition accompanied an open letter calling for Falah's release that was published in Ireland's national newspaper, Irish Times, on 25 July 2006. Bruce D'Arcus, a political geographer at Miami University in Oxford, Ohio, posted regular updates concerning Falah's case on his online blog. Keith Yearman, assistant professor of geography at the College of DuPage in Illinois, filed a Freedom of Information Act request for all official US State Department correspondence with Israel concerning Falah's case to be publicly released. The State Department's response was limited; they released official messages that included only summaries of news stories from around the world. Juan Cole, president of the Middle Eastern Studies Association (MESA), wrote a letter dated 25 July 2006 on behalf of MESA to Israeli Prime Minister Ehud Olmert, and to Israel's Minister of Justice and Attorney General, demanding due process for Falah. MESA posted Cole's letter on its website. These are just a few known examples of independent activities among scholars participating in the Free Ghazi campaign.

7 Colin Flint, Associate Professor of Geography at the University of IllinoisChampaign, is quoted in Inside Higher Education: “"This hits close to home,' he said. 'In a lot of discussions at conferences in recent years, we have all wrestled with the notion of self-censorship, about what we decide to do and say in class and in our research. Something like this turns that up a few degrees. But we must maintain the notion that in a free society, critical voices should be allowed to speak" (Lederman 2006).

\section{References}

AAG (2006) AAG supports member detained in Middle East. AAG Newsletter 4(8):9 Adams P C (1996) Protest and the scale politics of telecommunications. Political Geography 15(5):419-441

Adams P C (1998) Network topologies and virtual place. Annals of the Association of American Geographers 88(1):88-106

Agnew J (1997) The dramaturgy of horizons: Geographical scale in the "Reconstruction of Italy" by the new Italian political parties, 1992-95. Political Geography 16:99121 
Baran P (1964) On distributed communications: I. Introduction to distributed communications networks. Rand Corporation Memorandum RM-3420-PR. Santa Monica: The Rand Corporation

Biliczky C (2006) Israel detains Ohio professor. Akron Beacon Journal, 13 July 2006

Borgatti S P, Everett M G and Freemen L C (2002) UCINET 6.0 Version 6.200. Nantucket, MA: Analytic Technologies

Cox K R (1998) Spaces of dependence, spaces of engagement and the politics of scale, or: Looking for local politics. Political Geography 17(1):1-23

Cox K R and Wood A M (1997) Competition and cooperation in mediating the global: The case of local economic development. Competition and Change 2:65-94

D'Arcus B (2006) Boundaries of Dissent: Protest and State Power in the Media Age. New York: Routledge

Delaney D and Leitner H (1997) The political construction of scale. Political Geography 16:93-97

de Socio M (2007) Business community structures and urban regimes: A comparative analysis. Journal of Urban Affairs 29(4):339-366

de Socio M (2010) Marginalization of sunset firms in regime coalitions: A social network analysis. Regional Studies (forthcoming).

Falah G-W (1983) "The processes and patterns of sedentarization of the Galilee Bedouin, 1880-1982." Unpublished dissertation, University of Durham, Durham, UK

Falah G-W (1991) Scholarly openness and the role of Israeli Geographers. Journal of Geography in Higher Education 15(1):81-85

Falah G-W (1994) The frontier of political criticism in Israeli geographic practice. Area 26(1):1-12

Falah G-W (1996) On Israeli geographic practice: A brief response to Kellerman and thoughts on future prospects. Area 28(2):225-228

Falah G-W (2003) Dynamics and patterns of the shrinking of Arab lands in Palestine. Political Geography 22:179-209

Falah G-W (2007) The politics of doing geography: 23 days in the hell of Israeli detention. Environment and Planning D: Society and Space 25:586-593

Falah G-W (2008) Geography in ominous intersection interrogation and torture: Reflection on detention in Israel. Third World Quarterly 29(4):747-764

Froehling O (1997) The cyberspace "War of Ink and Internet" in Chiapas, Mexico. Geographical Review 87(2):291-307

Geletkanycz M A and Hambrick D C (1997) The external ties of top executives: Implications for strategic choice and performance. Administrative Science Quarterly 42(4):654-681

Gieseking J (2007) (Re)constructing women: Scaled portrayals of privilege and gender norms on campus. Area 39(3):278-286

Gravois J (2007a) An arrest on the border. The Chronicle of Higher Education 54(13):A1

Gravois J (2007b) Mapping out the interrogation of Ghazi Falah. The Chronicle of Higher Education 54 (13):A1

Grubesic T H, O'Kelly M E and Murray A T (2003) A geographic perspective on commercial Internet survivability. Telematics and Informatics 20:51-69

Hadlock C (2005) China toughens restrictions on internet news. MSNBC, 26 September. http://www.msnbc.msn.com/id/9489510/ Accessed 8 August 2008

Hafner K and Lyon M (1996) Where Wizards Stay Up Late: The Origins of the Internet. New York: Simon and Schuster

Hanson S (2000) Networking. Professional Geographer 52(4):751-758

Haunschild P R (1993) Interorganizational imitation: The impact of interlocks on corporate acquisition activity. Administrative Science Quarterly 38:564-592

Hyman A (2003) Twenty years of ListServ as academic tool. Internet and Higher Education 6:17-24 
Johnson-Eilola J and Selber S A (1996) Policing ourselves: Defining the boundaries of appropriate discussion in online forums. Computers and Composition 13:269-291

Jonas A E G (2006) Pro scale: Further reflections on the "scale debate" in human geography. Transactions of the Institute of British Geographers 31:399-406

Kirby A (1992) Publishing deca(ye)de. Political Geography 11:235-237

Lang J R and Lockhart D E (1990) Increased environmental uncertainty and changes in board linkages patterns. The Academy of Management Journal 33(1):106-128

Lederman D (2006) Israel releases detained Akron scholar. Inside Higher Education, 31 July. http://www.insidehighered.com/news/2006/07/31/falah Accessed 16 December 2007)

Leitner H and Miller B (2007) Scale and the limitations of ontological debate: A commentary on Marston, Jones and Woodward. Transactions of the Institute of British Geographers 32:116-125

Levia D F and Underwood S J (2004) Hydrological research and the status of physical geography journals: Increasing the impact of physical geography in the academy. Professional Geographer 56:345-349

Liebeskind J P and Oliver A L (2000) From handshake to contract: Intellectual property, trust, and the social structure of academic research. In C Land and R Bachmann (eds) Trust Between and Within Organizations: Conceptual Issues and Empirical Applications (pp. 118-145). Oxford, UK: Oxford University Press

Marston S A, Jones III J P, and Woodward K (2005) Human geography without scale. Transactions of the Institute of British Geographers 30:416-432

Masuda J R and Crooks V A (2007) Introduction: (Re)thinking the scales of lived experience. Area 39(3):257-258

McCoy A W (2006) A Question of Torture: CIA Interrogation, From the Cold War to the War on Terror. New York: Metropolitan Books

Miller B (1994) Political empowerment, local-central state relations, and geographically shifting political opportunity structures. Political Geography 13(5):393-406

Mintz B and Schwartz M (1983) Financial interest groups and interlocking directorates. Social Science History 7(2):183-204

Mintz B and Schwartz M (1985) The Power Structure of American Business. Chicago, IL: University of Chicago Press

Mizruchi M S and Stearns L B (1988) A longitudinal study of the formation of interlocking directorates. Administrative Science Quarterly 33(2):194-210

Morrissey J (2006) Professor charged with spying in Israel. Interview on Radio Telefis Eireannn, Dublin, Ireland. 27 July 2006. http://www.rte.ie/news/2006/0727/ 57live.html Accessed 20 December 2007

Myre G and Erlanger S (2006) Israelis enter Lebanon after attacks. New York Times, 13 July 2006

O'Lear S (1997) Electronic communication and environmental policy in Russia and Estonia. Geographical Review 87(2):275-290

Paasi A (2004) Place and region: Looking through the prism of scale. Progress in Human Geography 28(4):536-546

Quiring S M (2007) Trends in publication outlets of Geographer-Climatologists. Professional Geographer 59(3):357-364

Sheeran T J (2006) Geography professor detained in Israel. Associated Press 14 July

Staeheli L A and Thompson A (1997) Citizenship, community, and struggles for public space. Professional Geographer 49(1):28-38

Staeheli L A, Ledwith V, Ormond M, Reed K, Sumpter A and Trueau D (2002) Immigration, the internet, and spaces of politics. Political Geography 21:989-1012

Steinberg (1994) Territorial formation on the margin: Urban and anti-planning in Brooklyn. Political Geography 13(5):461-476 
Stone C N (1989) Regime Politics: Governing Atlanta, 1946-1988. Lawrence, KS: University of Kansas Press

Surborg B (2008) On-line with the people in line: Internet development and flexible control of the net in Vietnam. Geoforum 39:344-357

Traubmann T and Melman Y (2006) Canadian-Israeli prof. arrested on suspicion of spying for Hezbollah. Haaretz 26 July. http:www.haaretz.com/hasen/pages/ShArt. jhtml?itemNo=743154 Accessed 1 January 2008

Tretter E (2008) Scales, regimes, and the urban governance of Glasgow. Journal of Urban Affairs 30(1):87-102

Tuan Y-F (1977) Space and Place: The Perspective of Experience. Minneapolis: University of Minnesota Press

Warf B and Grimes J (1997) Counterhegemonic discourses and the Internet. Geographical Review 87(2):259-274

Wasserman S and Faust K (1994) Social Network Analysis: Methods and Applications. Cambridge, UK: University of Cambridge Press

Wood A (1993) Organizing for local economic development: Local economic development networks and prospecting for industry. Environment and Planning A 25:649-661

Wood A (2005) Comparative urban politics and the question of scale. Space and Polity 9:201-215

Yeung H W-C (1997) Business networks and transitional corporations: A study of Hong Kong firms in the ASEAN region. Economic Geography 73(1):1-25

Yeung H W-C (2005) The firm as social networks: An organizational perspective. Growth and Change 36(3):307-328 